\section{Deforestation, land conversion and illegal logging in Bangladesh: the case of the Sal (Shorea robusta) forests}

\author{
Kazi Kamrul Islam, Noriko Sato
}

Bangladesh, with a forest cover estimated at $\mathbf{1 7 . 0 8 \%}$ of all land surface area, has experienced massive degradation of its natural resources and a considerable change in its land cover. While deforestation in Bangladesh is obviously a complex issue, one important aspect emerges from previous research findings in explaining deforestation: industrialization. This study focuses on the causes of deforestation in Bangladesh, particularly in tropical moist deciduous Sal forests, using multi levels factor analysis framework. Data were collected through questionnaire surveys, formal and informal discussions with local people, expert interviews and literature reviews. The main findings of deforestation framework show that illegal logging and forest land conversion were the ultimate causes of Sal forests deforestation in Bangladesh. Illegal logging is a complex phenomenon and is being patronized by a local syndicate, functioning from behind the scenes. On the other hand, land conversion into different commercial activities has direct influence on national policy and the predisposing conditions of this country. Therefore, the immediate task of the nation would be to stop illegal logging and land conversion of Sal forests. This can be done by involving all relevant stakeholders in the form of effective forest policy formulation and execution of strict environmental protection law.

\section{Keywords: Sal Forests, Deforestation, Land Tenure, Forest Policy, Corruptions}

\section{Introduction}

Deforestation is considered one of the oldest problems of the world, and it is as old as the agricultural revolution 10000 to 12000 years ago (Mena 2001). People have always needed land for their own uses and have consequently cleared natural vegetation. Nowadays, global deforestation is understood to be one of the key problems of climate change (FAO 1995, Turner 1996, Cassel-Gintz \& Petschel-Held 2001, Gorte \& Sheikh 2010). Moreover, the economic value

$\square$ Graduate School of Bioresources and Bioenvironmental Sciences, Kyushu University, Hakozaki, Higashi, 812-8581 Fukuoka (Japan)

@ Kazi Kamrul Islam

(kamrulbau@yahoo.com)

Received: Jan 27, 2011 - Accepted: Apr 12, 2012

Citation: Islam KK, Sato N, 2012.

Deforestation, land conversion and illegal logging in Bangladesh: the case of the Sal (Shorea robusta) forests. iForest 5: 171-178 [online 2012-06-25] URL:

http://www.sisef.it/iforest/contents? id=ifor0578-005

Communicated by: Renzo Motta ficant rate, nearly close to destruction (Safa 2004, Alam et al. 2008). As a consequence, about $36 \%$ of the Sal forests original cover existed in 1985, and more recent estimates mentioned that this figure dropped down to only $10 \%$ (Alam et al. 2008, FAO 2003).

Several researches dealing with deforestation have been undertaken, focusing on both the microeconomic (Repetto 1988, Gillis 1988 ) and macroeconomic causes of rapid deforestation in the tropics (Shafik 1994, Capistrano \& Kiker 1995, Khan \& McDonald 1995). However, the relevance of understanding the deforestation systems goes beyond the capability to point out the changes resulting from deforestation; it is necessary to realize its causes and effects on natural resources (Mena 2001). Scientists generally mention population pressure and rural poverty as a key element in explaining deforestation of Bangladesh. However, other scientists and environmental groups have referred forest shrinkage to economical growth, national policies, and the harvesting of trees for firewood (Salam \& Noguchi 1998). Empirical support for these hypotheses is fundamentally applicable for all forest types of Bangladesh. Deforestation in Bangladesh is obviously a complex issue and, moreover, scanty scientific studies have been carried out to identify its deep causes, particularly in Sal forests, which is the most threatened ecosystem of the country (Safa 2004, Alam et al. 2008). At the background of such apocalyptic situation, this study has been carried to deepen understanding of the deforestation process through exploring the sources and the underlying and immediate causes of Sal forests deforestation.

\section{Theoretical framework}

A wide diversity of deforestation concepts, estimates, measurements and predictions were carried out throughout the world and the difficulty of the problem has taken some studies to categorize the interaction of tropical and sub-tropical deforestation causality into several groups (Zikri 2009). They can be defined usually as proximate (or direct) causes and underlying causes of deforestation (Rowe \& Sharma 1992, Geist \& Lambin 2002). Besides these two categories, Angelsen \& Kaimowitz (1999), and ContrerasHermosilla (2000) added one more group of variables: sources (agents) of deforestation (Fig. 1). This study uses a narrow definition of Wunder (2000) of deforestation, which refers to the clearing of forest habitats to be converted to non-forested areas, such as agriculture, bare soil, human settlement, industries, pastures, etc. and follows Angelsen \& Kaimowitz (1999) multilevel frameworks for explaining the causes of tropical moist deciduous forest, i.e., Sal forests deforestation. 
Fig. 1 - Main causes of Sal forests deforestation at various levels. This framework is adopted from Angelsen \&

Kaimowitz (1999) deforestation model.
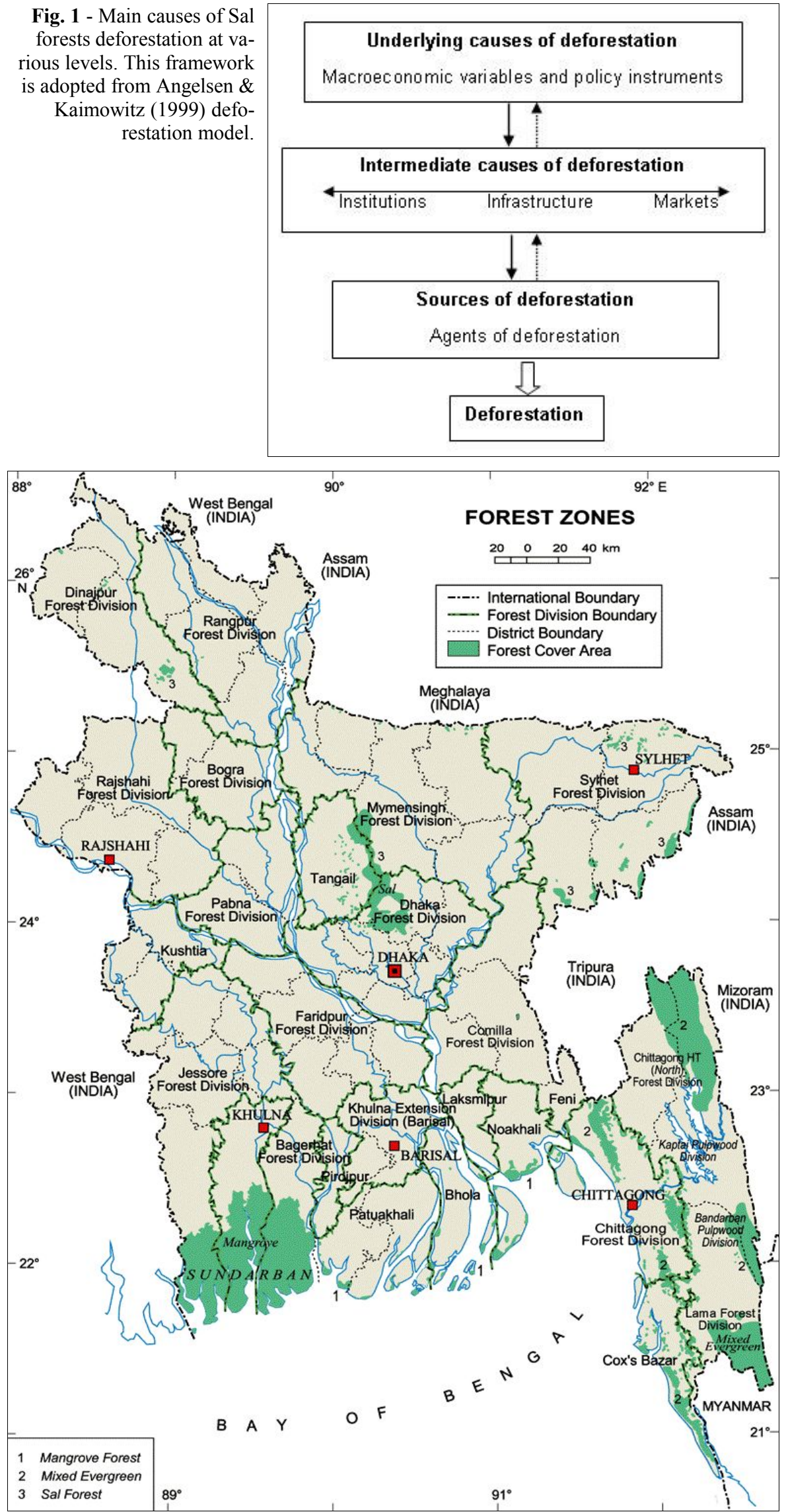

Fig. 2 - Forest cover map of Bangladesh and the study area. Source: GOB 2010.

\section{Materials and Methods}

\section{Study area}

Sal forests constitute about $10 \%$ of the total forest land (a total of 0.12 million ha) of Bangladesh (GOB 2010). Until the beginning of the $20^{\text {th }}$ century, these forests existed as a continuous belt from the central and northern parts of Bangladesh. Nowadays, they exist mainly in the central part of this country, which is mainly located in the Gazipur, Dhaka, Mymensingh and Tangail districts (Alam et al. 2008 - Fig. 2). The Sal forests ecosystem supports a rich and diverse variety of flora and fauna, though Sal tree (Shorea robusta) is the dominant tree species (more than $80 \%$ in volume - Green 1981, Khan et al. 2007). Out of four categories of forest type in Bangladesh, plain land Sal forests are the most endangered and threatened one, having already faced severe deforestation problems (Safa 2004, Ali et al. 2006). Therefore, this study was conducted at the Central Sal forests of Bangladesh (Fig. 2).

\section{Data Collection}

The study was based on different sources and methods for collecting primary and secondary data, i.e., several data collection techniques. For primary data we used formal and informal discussion with local people, expert interviews, a case study and direct field observations. On the other hand, secondary/literature review were collected through field documents and project reports, peer-reviewed journals, making use of Bangladesh Forest Department library, exploring reliable relevant online sources and related books. A random sample of 120 forest dependent people was selected (for case study) in equal number for each of the twelve Beats (lowest administrative unit of Forest Department) under the five Ranges (a range has one to several Beats) of the Madhupur Sal forest. Two ethnic minorities (Garo and Koch) have been living all over the Madhupur Sal forest area from time immemorial (Gain 2002). So, the sample population consisted of 60 ethnic and 60 non-ethnic forest dependent people of various ages, ranging from 22 to 65 years. Of the respondents engaged in the case study, about $85 \%$ were illiterate and only $10 \%$ were female. The majority of the respondents (about 63\%) were day laborers and subsistence agriculture farmers. Further, this study covered the opinions of four "Range Officers" and the Assistant Conservator of Forest (ACF) in Madhupur Sal forest, together with eight scientists working on Sal forests (selection based on their published books/article/research on Sal forests). The whole study was conducted during the months of July-October 2010, and the case study was conducted in September-October 2010 by a research team consisting of three 
members (two enumerators) and using a semi-structured questionnaire whose purpose was to collect information regarding socio-economic aspects of the households and causes of Sal forests deforestation in the study area. Socio-economic questions consisted of mainly structure format (e.g., answers via multiple choice, yes/no or category). On the contrary, causes of deforestation and respondents opinion were identified through open-ended questions. A total of 29 questions were included in the pretested questionnaire, and the language used during the interview was Bengali. Finally, the primary and secondary data were processed and interpreted according to the framework of this study.

\section{Results and Discussion}

\section{Underlying causes of deforestation}

The underlying causes of deforestation are those factors which may also create an environment where further deforestation can occur. Moreover, these causes of deforestation may widely affect all aspects of society, yielding some of the most systemic and most complicated feedback that frustrate human progress and sustainable development.

\section{Population growth and poverty}

About 50000 people, including ethnic minorities, have established in Madhupur Sal forest area during the last forty years (Rahman 2010) also attracted by the greater productivity of this area (Safa 2004). Most of the respondents (approximately 87\%) of this study were of the opinion that, in the last two decades, the population of the forest adjacent areas and illegal houses (inside the forest area) has been doubled and that the majority of that population depends on forest for their livelihood. The exact number of people who live by exploiting Sal forests for their subsistence is not known, but the FD has identified at least 5000 households in Madhupur Sal forest area (GOB 2010). In the case of Bangladesh, the population increase is said to be foremost due to the general causes of deforestation (Salam \& Noguchi 1998, Gain 2002,). Tab. 1 shows high population growth and settlement rates in Gazipur, Tangail and Mymensingh districts Over population and resulting settlement, also implying the development of road networks and other infrastructure, has had a negative impact on the forest and its wildlife (Rahman 2010), continuously degrading the forest resources.

Another predisposing condition of deforestation is poverty that affects the majority of people in Bangladesh. Poverty is the socio-economic environment that limits peoples' economic options, damages health, restricts the arrangement of rural capitals, decreases potential income that can create op-

Tab. 1 - Population size, growth rate, density and poverty rate of major settlement near Sal forests area of Bangladesh. (HCR): Head Count Rate in upper poverty levels. Sources: BBS 2007, Banglapedia 2010.

\begin{tabular}{lcccc}
\hline Location & $\begin{array}{c}\text { Population } \\
\text { size }\end{array}$ & $\begin{array}{c}\text { Annual } \\
\text { growth rate }\end{array}$ & $\begin{array}{c}\text { Population } \\
\left.\text { density } \mathbf{( k m}^{2}\right)\end{array}$ & $\begin{array}{c}\text { Poverty } \\
\text { (HCR) }\end{array}$ \\
\hline Mymensingh sadar & 225811 & $2.5 \%$ & 10392 & $48-60 \%$ \\
Tangail sadar & 128785 & $2.2 \%$ & 3650 & $36-48 \%$ \\
Gazipur (Sadar and Tangi) & 588492 & $4.0 \%$ & 2505 & $21-36 \%$ \\
Bangladesh & 158065841 & $1.2 \%$ & 1146 & $31.2 \%$ \\
\hline
\end{tabular}

portunities, and limits physical and institutional development (Martin 1999). This case study found that about $53 \%$ of ethnic and $26 \%$ of non-ethnic (average $40 \%$ ) respondents were unable to meet their food requirement throughout the year (Tab. 2), while only $10 \%$ participants were able to do it for half a year only (Tab. 2). Without having other secure alternative income sources and being limited the scope for off-farm employment in either rural areas or urban centers, respondents have been exploited Sal forests to support their daily living. Further, illiteracy limits the options for poor people because they do not have the fundamental tools required to pursue other economic alternatives to subsistence farming. In Sal forest areas, poor people migrate from overpopulated, depressed regions to the forest edge in search of a more prosperous and secure life, with a very high rate for non-ethnic people (Tab. 2, Fig. 3).

\section{Land tenure and access}

In this study, about $96 \%$ of respondents, questioned on their access rights to Sal Forest, agreed that they do not have any formal free access rights, though they have always collected firewood and NTFPs from Sal forests without any protection by local Forest Department. Moreover, it clearly

Tab. 2 - Household size, main income sources, food sufficiency and settlement status of the respondents.

\begin{tabular}{lccc}
\hline \multirow{2}{*}{ Characteristics } & \multicolumn{3}{c}{ Respondents } \\
\cline { 2 - 4 } & Ethnic & Non-ethnic & Average \\
\hline Household size (Mean \pm SD) & $5.62 \pm 1.40$ & $5.44 \pm 1.32$ & 5.33 \\
Households main sources of income & & & \\
- Daily wage labor & $51.66 \%$ & $41.66 \%$ & $46.66 \%$ \\
- Subsistence Agriculture & $10 \%$ & $23.33 \%$ & $16.67 \%$ \\
- Unemployment & $23.33 \%$ & $15 \%$ & $19.17 \%$ \\
- Fuelwood and NTFPs collection from forests & $11.66 \%$ & $3.33 \%$ & $7.5 \%$ \\
- Others & $3.33 \%$ & $16.66 \%$ & $9.96 \%$ \\
Food sufficiency & & & \\
- Whole year (12 month) & 0 & $1.66 \%$ & $0.83 \%$ \\
- Half of the year (6 month) & $6.66 \%$ & $13.33 \%$ & $9.96 \%$ \\
- 2 to 3 months only & $40 \%$ & $58.33 \%$ & $49.17 \%$ \\
- Not at all & $53.33 \%$ & $26.66 \%$ & $39.96 \%$ \\
Distribution of households as origin & & & \\
- From same area/village & $88.33 \%$ & $16.66 \%$ & $52.5 \%$ \\
- From same district (not same village) & $8.33 \%$ & $38.33 \%$ & $23.33 \%$ \\
- From other district & $3.33 \%$ & $45 \%$ & $24.17 \%$ \\
- From other country & 0 & 0 & 0 \\
\hline
\end{tabular}

emerges from literature reviewed that the arable land, too limited and less and less economical, cannot support the growing population. Individual farms, passing on from generation to generation through inheritance, become smaller and less productive and, furthermore, most of the truly arable land is held by the powerful landowners or by corporations. Within this situation, the only solution for most poor families is to either move to town or relocate to the forest frontier to clear the trees to make new households, while government attitude, considering forestland issues politically less important, is to ignore deforestation rather than facing the critical matters of land conversion, employment opportunities, and population control.

Land tenure obviously has an important influence (Muhammed et al. 2005) on ethnic peoples' attitude towards land use. The ethnic minorities, especially the Garos, also known as Mandis, would take the responsibility to create and tend the forest. Even during the British colonial period, jum (slush and burn) cultivation was allowed in the Madupur Sal forest area, the natural forest remained intact and forest people lived in peace (Gain 2002). The same policy was carried out by the Zamindar (Landlord), more interested in collecting taxes than in Sal

\section{- From other country}




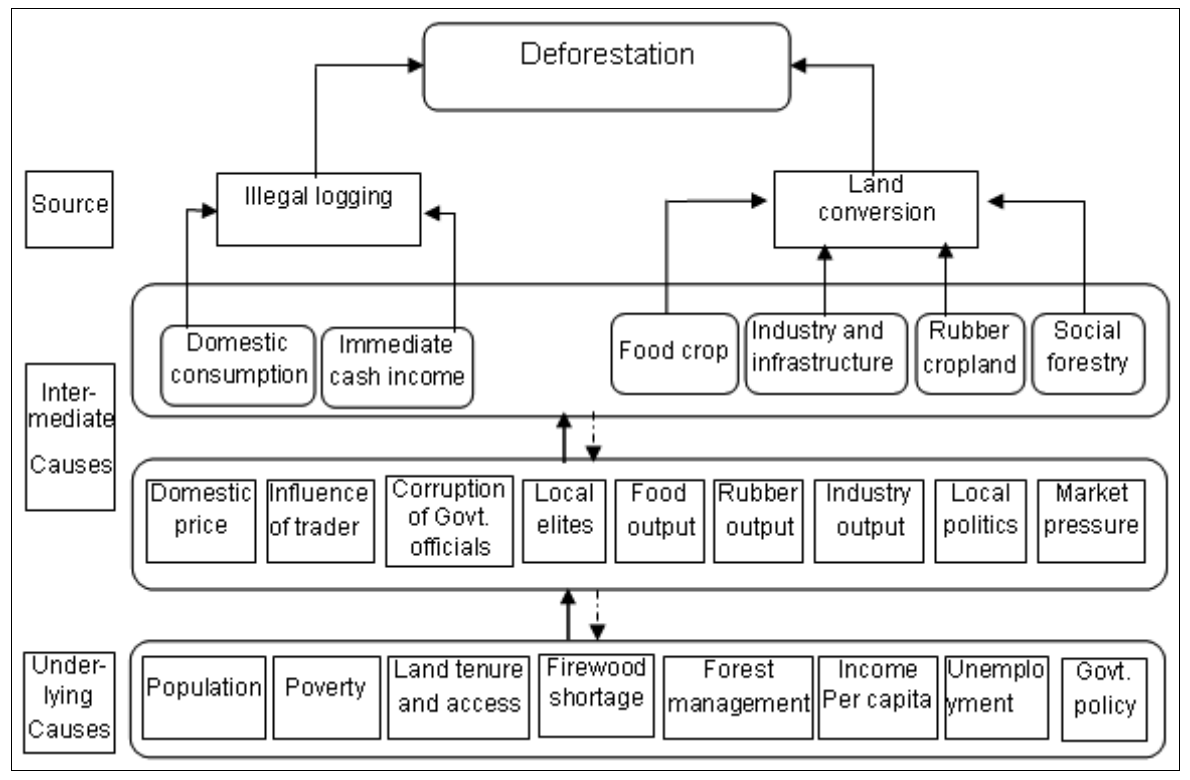

Fig. 3 - Different factors affecting Sal forests deforestation in Bangladesh.

forests conservation. In 1950, the Pakistan government formulated the "East Bengal State Acquisition and Tenancy Act" (EBSATA), which abolished the Zamindar system (Salam \& Noguchi 2005). Since then, Forest Department (FD) took control of forests and thus started the conflict with ethnic minorities about the land tenure and user rights. Ethnic minorities tried to manage the forest in their own traditional ways, but the FD did not allow them to do so. Day by day the situation still worsens; a Garo man (Bihen Norek) was killed on April 10, 1996 (Gain 2002). Under these circumstances, illegal logging and clearing the forest continue. In this case study, one Garo person said: "We were born here; we were grown up here and even we want to die here"; and another person added that: "We will not handover our traditional land to the FD until we are dead". Further, in this study every ethnic respondent $(100 \%)$ mentioned that they want to get back their traditional land user rights and they are willing to clear forest land to achieve this goal. So, this situation has encouraged deforestation and seeks immediate steps from the top level of Bangladesh.

\section{Forest management and policy}

Most of respondents (about 95\%) while ignoring specific details of forest policy, believe that the land concession act (all forest land owned by the government) was deeply unfair for all forest dependent people. Review of literature summarized that the history of the forestry in Bangladesh is one of continuous reduction of forest resources both in terms of area and quantity (FMP 1992, Ahmed 2008). Furthermore, ineffective and bureaucratic forest management approaches have an immense impact to the deforestation of most state forests in Bangladesh (Ahmed 2008, Khan 1998). In the Indian sub-continent, scientific forest management started during the British period (colonial), and a separate forest department was established for Bengal in 1876 (Ahmed 2008). In the Sal forests case, they initially belonged to landlords and were put under scientific management in 1950s (Salam \& Noguchi 2005), when forest department gradually took its responsibilities. It was introduced a silvicultural management plan, which included clear felling with regeneration from coppice with a rotation of about twenty years (Ahmed 2008). In addition, thinning was applied on a ten year cycle to improve the Sal stock and plantations executed under a taungya system (Ahmed 2008). Because of huge pressure from an over-growing population and poverty, none of these plans could sustain proper management of Sal forests, which has continued to decrease in quantity and quality. FAO (2000) reported that if these Sal trees are provided with sufficient protection, then they can still be able to regenerate and grow.

On the other hand, Bangladesh Forest Policy of 1894 provided the main guidelines for the formulation of laws and regulations

Tab. 3 - Present social forestry programs in Madhupur Sal forest area of Bangladesh. Source: GOB 2010.

\begin{tabular}{lcl}
\hline $\begin{array}{l}\text { Social Forestry } \\
\text { Programs }\end{array}$ & $\begin{array}{c}\text { Area } \\
\text { (ha) }\end{array}$ & Remarks \\
\hline Woodlot & 1382 & $\begin{array}{l}\text { Cash income; enhance deforestation and } \\
\text { negative ecological impact }\end{array}$ \\
Agroforestry & 525 & $\begin{array}{l}\text { Subsistence and cash income; increase de- } \\
\text { forestation and negative ecological impact }\end{array}$ \\
$\begin{array}{l}\text { Sal coppices management } \\
\text { Buffer zone management }\end{array}$ & 702 & $\begin{array}{l}\text { Totally failure and land conversion } \\
\text { Mostly failure and land conversion }\end{array}$ \\
\hline
\end{tabular}

Total

Participants for managing forests. Review of literature also found that the primary attempt to articulate the need of conserving forest resources was made in 1855 by the government of British India (Ahmed 2008). After the separation of India in 1947, the policy was not appropriate for the new state of East and West Pakistan (Banglapedia 2010, Ahmed 2008). The offered policy neither considered the enlargement of forest resources nor highlighted sustained crops from existing forests. Then, a new policy was announced in 1955 according to the guideline of the Pakistan Forestry Conference held in 1949, so initiating in 1962 a new political course. A course that gave emphasis to the exploitation of forest products and did not help the sustainable development of forestry in Bangladesh (former East Pakistan).

After liberalization (in 1971), the Bangladesh government formulated a policy statement in 1979, where there was no clear reference to functional classification and use of forest land, sustainable productivity, community participation, etc., and, as a whole, it was very general and unclear (Ahmed 2008). As a result, the government decided to adjust the forest policy of 1979, approving Forest Policy of 1994. Moreover, a twenty year Forestry Sector Master Plan (FSMP 19932013) was approved in 1990s, whose main objective was to bring $20 \%$ of the country's land under tree cover. The latest Forest Policy of 1994 showed an equitable benefit sharing systems with the local people, and it also enhanced people participation in forest management activities. However, there was no clear, detailed guideline of participatory/ social forestry approaches and a planning and decision making process in that forest policies which were worked out without a complete understanding of all the issues concerned and all the probable impacts. Decisions are made only by the political decision-makers, without taking into account the real needs of the poor forests dependent people and value of forests (GOB 2010). All this probably also due to the general weakness of the national forest institution and its inefficiency to formulate and execute sound policies. For example, the rubber plantation program in the Sal forest areas in 1982 was totally an immature decision by the top level policy makers of FD (Gain 2002) because it 
Fig. 4 - Different biomass fuel sources used by the respondents in

Sal forests area of Bangladesh.

$\mathrm{CD}$ and SF indicate Cow Dung and Social Forestry, in Sal forests area.

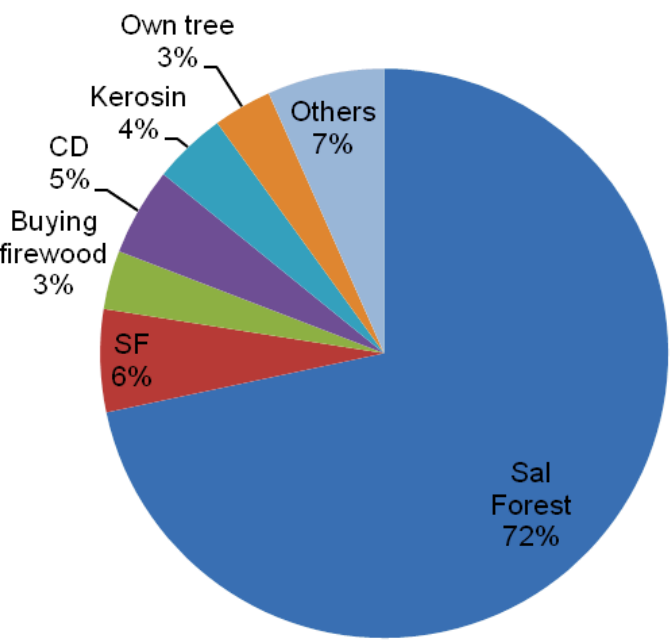

was neither environmentally feasible nor economically profitable. If the situation remains as it is, no policy, rules and regulations will be able to restore the valuable natural resources in the Sal forests.

\section{Industrialization and infrastructure deve- lopment}

Of the respondents involved in this study, about $90 \%$ asserted that the rapid industrial development into Sal forest areas has an enormous negative impact on forest cover and degradation. They also argued that it is a real threat for their future survival as a forest dependent people. Literature also reaches the same conclusion, pointing out industrialization as one of the main causes degradation in the Sal forest area (Ahmed 2008). This phenomenon is especially common in the Gazipur and Dhaka Sal forests area; since it is close to the capital city of Bangladesh, a lot of industries are building there their plants and land has been taken by powerfu elite people both politically and economically. But even towards this issue government policy is not clear or transparent, and in many cases, it favors elite individuals or companies, representing one of the major threats for ecological stability of Sal forests. Further, infrastructural developments like new roads building, worsens forest land destruction. In one example, two road networks totalizing $62.2 \mathrm{~km}$ of length have been constructed in the Madhupur Sal forests area (GOB 2008), isolating the population of wildlife and grabbing natural forest covers In addition, a firing range of Bangladesh Air Force (BAF) which was established on about 405 ha of Madhupur Sal forest land (Gain 2005, Rahman 2010) is an additional evidence of land conversion of Sal forests in Bangladesh.

\section{Firewood shortage}

Some $72 \%$ of respondents to the questionnaire relies on forests as a source of their firewood (Fig. 4). Though controlled firewood collection from Sal forests is not completely destroying the forests and woodlands, its massive collection might affect the regeneration and conservation of forests. On the other hand, firewood is the most important wood product in Bangladesh, and the estimated demand and supply for the years 1993 to 2013 (by FMP) shows that firewood is almost one-third of the total demand (Akther et al. 2010). The gap between demand and supply of firewood would easily explain the national crisis of firewood in Bangladesh. Firewood is collected mostly in uncontrolled and illegal ways, and as a consequence, species in the Sal forests are experiencing reduction day by day. Therefore, firewood crisis throughout the whole Bangladesh is an underlying cause of Sal forests deforestation.

\section{Unemployment and poor income}

This case study found that about $20 \%$ respondents were jobless and passing daily life without any food security (Tab. 2). In addition, about $52 \%$ ethnic and $42 \%$ non-ethnic respondents were daily wage laborers: these jobs are not always reliable, and sometimes they passed long periods without any income. The people of the forest frontier zone live under the poverty line, and the majority of them are landless farmers and landless agricultural laborers. The average per capita income of Bangladeshi people is only US\$ 1.465 (adjusted by Purchasing Power Parity) in 2010, which is far higher than average per capita forestry area income (Ahmed 2008). This case study revealed that about $70 \%$ of the people living inside the Sal forests area are agricultural laborers and subsistence farmers (Tab. 2). The average working time of a day laborer in Madhupur Sal forest area is more than 8 hours, whereas the average wage is only US\$ 1.6 per day. Within this poor income, the landless agricultural laborers cannot buy their food for their daily living. Furthermore, these poor and illiterate people cannot find alternative livelihood opportunities other than extracting resources from the Sal forests, increasing pressure and illegal logging of them.

\section{Intermediate causes of deforestation}

Intermediate causes are not directly visible but mostly interlinked variables that are readily associated with the agents/sources of deforestation. Sometimes they are driven by the top level forces, i.e., associated with the underlying causes of deforestation.

\section{Corruption at local level}

In formal and informal discussion with local people, this study found that a few of the local elites along with some members of political parties (both strongly connected with the local police department) are indirectly responsible for the illegal logging of Sal forests. Corruption in the FD has had a terrible impact on forest conservation (Gain 2002, Ahmed 2008). Forest officials have often covered the illegal activities of the so called "Musclemen" and used to take bribes regularly from the corrupted timber merchants and from brick kiln and sawmill owners, who used illegal Sal timber.

Moreover, all of the respondents $(100 \%)$ of Madhupur Sal forest area added that the dishonest FD staff and guards helped the illegal loggers (poor villagers) to make a safety path (locally called "line") to carry the felled trees to the nearest trader place. In contrast, the FD staff argued that illegal loggers (usually poor villagers, who usually work for the dishonest traders, as mentioned by Ahmed 2008) were supported and paid by the local sawmills and brick kilns owners in order to get Sal timber. Then coming to the strong linkage of influential elites with local police department (Gain 2002), the majority of the respondents (more than $90 \%$ - Fig. 5) said that the poor people of the Sal forests areas were sometimes being convicted by the forest officials or the local elites for the theft of trees (if did not follow the instructions for illegal felling), even though most of the time the accusations were false. As a consequence, the local people treated the FD as their opponents or enemy; this situation might directly influence illegal logging or deforestation of the Sal forests.

On the other hand, the FD is maintained by poorly paid staff, insufficient budgets, being short-staffed, and lacking of staff training facilities. For example, one of the Ranger Officers (RO) of Madhupur Sal forest claimed that he did not receive any office management payment or even compensation for the cost of fuel for his motorbike for the last five years. It is clear that the departments have been ineffective, corrupted or not successful in handling the huge forest areas (Salam \& Noguchi 1998, Gain 2002, Ahmed 2008). 


\section{Domestic consumption and market situa- tion}

Market demand and the growing needs of timber of the overpopulated country of Bangladesh are other causes contributing to the depletion of forest resources and encouraging illegal loggers to cut down the trees from forests area. Sal timber demand has reportedly been increased especially for making doors and windows frames, furniture and ornamentation of households (Banglapedia 2010), and even people who have inadequate income want to have wooden furniture like they see on television or in furniture company advertisements (Ahmed 2008, Banglapedia 2010). This study found that on an average $1 \mathrm{~m}^{3}$ of Sal timber (good quality $\log$ ) was sold at US\$ $300-400$, which is one of the highest values in the Bangladesh market so most of the local traders wanted to buy Sal timber and often they gave advanced money to illegal loggers or the syndicate (as already explained), ultimately enhancing deforestation.

This market situation of Bangladesh is a part of global capitalism where the demand for consumer goods is constantly increasing. However, this study could not deny the importance of our consumption patterns to the exploitation of forest land. What is debatable is the importance of collecting timber in sustainable ways or through scientific approaches.

\section{Commercial agriculture and rubber plan- tation}

About $96 \%$ of the respondents in this study argued that depleted Sal forest lands were converted to commercial agriculture and rubber plantations, under control of local elites and FD. Commercial agriculture occupies the best and most fertile land: important crops in that area include rice, pineapple, banana, rubber, aroid, turmeric, zinger, papaya, citrus, etc. (Banglapedia 2010, Gain 2002) As a consequence farming families have had to relocate to less productive areas and the Sal forests have been reduced by more than $50 \%$ since the 1970s (FAO 2003). Further, agribusiness companies (e.g., food processing factories) initially took the land for agricultural activities through a concession agreement, but soon after they converted it for other uses. It addition, the massive use by commercial agriculture of agrochemicals, pesticides and growth hormone has had a negative environmental impact, causing the entire area of Madhupur Sal forest to experience severe soil and air pollution (Gain 2002, 2007).

The rubber plantation program was started in 1986, and initially 6070284 hectares of forestland were covered (GOB 2010, Gain 2002) in the Madhupur Sal forest area. But respondents and local people claimed that plantation expanded not only to the ap-

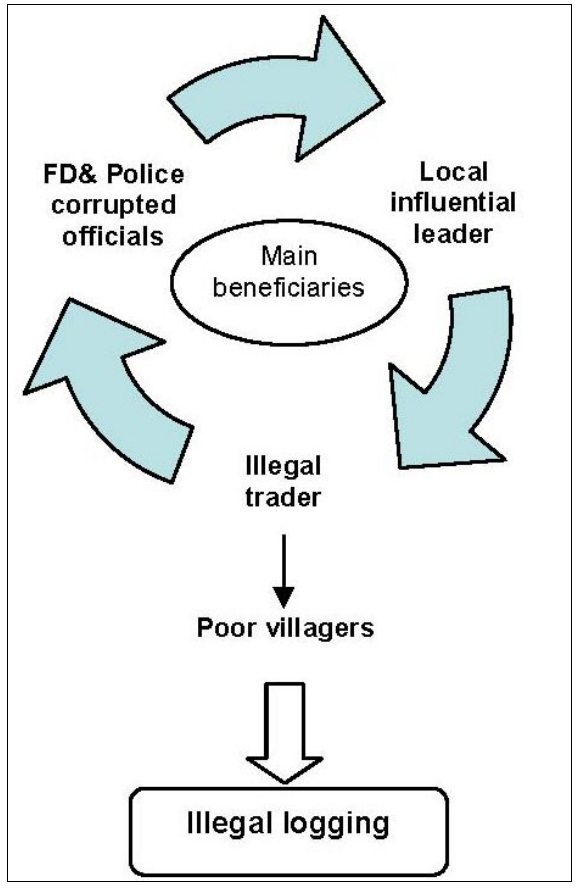

(Gain 2005, Salam \& Noguchi 2005, Alam et al. 2008, Rahman 2010). In 1989, a giant project was launched by the ADB for helping the local people through a participatory management approach and, four types of different management programs were implemented by the local FD in the Madhupur Sal forest area; of them the woodlot is the dominant one. This study found that out of the four programs, only the woodlot and agroforestry programs were running. Two other programs, namely sal coppice management and buffer zone management, totally failed (Tab. 3), as reported by the GOB (2010). Moreover, the failure plots were encroaching by the local elites, and this study discovered that in most of the cases, land was used for commercial agriculture (e.g., banana cultivation).

Experts argue that exotic species are harmful to biodiversity of the area and may transform the local ecosystem into a dry landscape even due to their ever-increasing need for water (Hossain 2005, Rahman 2010). Over the last twenty years, the Sal forests have decreased drastically due to new plan-

Fig. 5 - Channels of illegal logging in Sal forests of Bangladesh. FD indicates local Forest Department of Bangladesh.

proved land but also to the traditional settlement area of Garos and other ethnic minorities. From the FD point of view the program was an afforestation opportunity and economically profitable. So far, the example set by this rubber plantation scheme was contradictory and exposes opposite views (Gain 2002). However, so far, while it is not yet possible to determine whether rubber plantations will reach their goal and be a benefit to local communities and to the national economy, the environmental and social impact is evident and equally clear is the will of local populations not to allow further expansion of commercial agriculture on their territories

\section{Social forestry}

In this case study, the respondents were giving different opinions about social forestry programs; some of them said it increased income and others thought it hindered Sal forests ecology and biodiversity. However, about $90 \%$ of the respondent argued that the plots where social forestry/participatory forestry failed were converted into commercial agriculture. The literature reviews support that alien invasive plantation has been carried out throughout major Sal forest areas with financial support of Asian Development Bank (ADB), World Bank and other donor agencies since 1982 (Muhammed et al. 2008). The Sal forests have become exhausted in recent times due to commercial rubber plantations and social forestry and participatory forestry activities tations with alien species (Gain 2007, Hossain 2005). Further, these social forestry programs significantly influenced the local poor people to clear the forest edge and to stop the natural regeneration of Sal coppices (Gain 2002). So, replacing the natural forest with plantations results in a loss of natural forest cover, causes deforestation and also changes land use pattern in Sal forests of Bangladesh.

\section{Sources of deforestation}

Sources of deforestation are those factors which combine underlying and intermediate causes of deforestation. They are conditions/ agents created by the local situation, at times human nature. After exploring all possible causes, this study has pointed out that illegal logging and forest land conversion are the main sources of Sal forests deforestation in Bangladesh. In field visit, this study identified that individuals or a group of individuals were the main elements of Sal forests encroachment (also mentioned by Pant 1990), which enhance deforestation in a collective manner. Local institutions or companies did not take part in illegal logging activities, but they had a remarkable influence on illegal loggers. Sometimes illegal trees are marked by the dishonest FD staff and transported in vans, rickshaws, buffalo carts (local vehicle) and trucks without any resistance by the local police department. Gain (2002) and Ahmed (2008) also indicated such types of corruption by local FD staff, which stimulates illegal logging of Sal forests in Bangladesh. The organized illegal loggers sometimes use the poor people for cutting and transporting the trees for wages. macro level and at times the consequences of 
Moreover, high market demands and domestic consumptions of Sal timber have a strong linkage to the illegal logging of Sal trees. In addition, rural poverty, population growth and the unemployment situation of this country trigger poor villagers to illegally participate in logging activities. On the contrary, Sal forest land conversion into commercial agriculture, industries, infrastructure and others have direct influence on macro (underlying) and mid level (immediate) factors of this country. Therefore, illegal logging and land conversion are the most systemic and chain causes that enhance deforestation and also hinder sustainable conservation of Sal forests.

\section{Conclusion and policy implications}

This study has attempted to develop a complete scenario of the causes of Sal forests deforestation in Bangladesh. The findings of this study clearly indicate that illegal logging and forest land conversion into different commercial activities are important sources for deforestation. These two agents have been immensely influenced by local corruption and politics along with weak government policies and institutional weakening. However, the predisposing conditions of this country also have an influential effect to the deforestation, and this would be implemented by sustainable alternative livelihood ap proaches, which provide immediate benefits to poor households. At the same time, Sal forests management will need to be modernized through a long-term forest master plan, including all relevant stakeholders in this process. Granting land rights to the ethnic minorities and taking rigorous measures for enforcing the forest law are also important tasks for the government to protect deforestation. This study also concludes that commercial interferences which are destructive to forest lands should be strictly banned, and an effective policy should be adopted. In addition, there is an urgent necessity to strengthen the forest department through appointing well-trained and motivated forestry professionals, allocating sufficient budget, and developing infrastructures. Finally, the future survival of the Sal forests in Bangladesh depends on the development and effective implementation of forest laws and sustainable forest management plan.

\section{Acknowledgements}

We gratefully acknowledge "Fuji Xerox the Setsutaro Kobayashi Memorial Fund" and Interdisciplinary Programs in Education and "Projects in Research Development (P\&P Program)", Kyushu University, Japan for providing financial support to this research.

\section{References}

Ahmed FU (1999). Summary of the social forestry programs of the Bangladesh Forest Department. The Bangladesh Agroforestry Newsletter 9: 1-2. Ahmed MU (2008). Underlying causes of deforestation and forest degradation in Bangladesh. A report submitted to Global Forest Coalition (GFC), the Netherlands.

Akther S, Miah MD, Koike M (2010). Domestic use of biomass fuel in the rural Meghna floodplain areas of Bangladesh. iForest 3: 144-149. doi: 10.3832/ifor0551-003

Alam M, Furukawa Y, Sarker SK, Ahmed R (2008). Sustainability of Sal (Shorea robusta) forest in Bangladesh: past, present and future actions. International Forestry Review 10 (1): 2937. - doi: 10.1505/ifor.10.1.29

Ali M, Kabir MA, Hoque ATMR (2006). People, policy and perpetuity: sustainability indicators of Bangladesh forestry. Electronic Green Journal 1 (24): Article 3. [online] URL: http://escholarship.org/uc/item/2c34v67q

Angelsen A, Kaimowitz D (1999). Rethinking the causes of deforestation: lessons from economic models. The World Bank Research Observer 14 (1): 73-98. - doi: 10.1093/wbro/14.1.73

Banglapedia (2010). National Encyclopedia of Bangladesh. Web Site [online] URL: http://www.banglapedia.org/httpdocs/english/index.htm

BBS (2001). Statistical year book of Bangladesh. Bangladesh Bureau of Statistics, Government of people's Republic of Bangladesh, Dhaka, Bangladesh.

BBS (2007). Statistical pocket book, Bangladesh.Bangladesh Bureau of Statistics, Government of Bangladesh, Dhaka, Bangladesh.

Capistrano AD, Kiker CF (1995). Macro-scale economics influences on tropical forest depletion. Ecological Economics 14: 21-29. - doi: 10.1016/0921-8009(95)00008-W

Cassel-Gintz M, Petschel-Held G (2001). GISbased assessment of the threat to world forests by patterns of non-sustainable civilization nature interaction. Journal of Environmental Management 59 (1): 279-298. - doi: 10.1006/jema.2000.0370 Contreras-Hermosilla A (2000). The underlying causes of forest decline. Occasional Paper No. 30, CIFOR, Bangor, Indonesia.

FAO (1995). Forest resources assessments 1990: Global Synthesis: FAO forestry paper, 124, Rome, Italy.

FAO (2000). FRA 2000 forest resource of Bangladesh country report. Food and Agriculture Organization, Rome, Italy.

FAO (2003). State of world's forest. Food and Agricultural organization, Rome, Italy.

FMP (1992). Forest management. Forestry master plan. UNDP/FAO BGD 88/025.I, Ministry of Environment and Forests, Government of Bangladesh, Dhaka, Bangladesh.

Gain P (2002). The last forest of Bangladesh. Society for Environmental and Human Development (SEHD), Dhaka, Bangladesh.

Gain P (2005). Bangladesher Biponno Bon. SEHD, Dhaka, Bangladesh. [in Bengali]
Gain P (2007). Stolen forest. Society for Environmental and Human Development (SEHD), Dhaka, Bangladesh.

Geist HJ, Lambin EF (2002). Proximate causes and underlying driving forces of tropical deforestation. Bioscience 52 (2): 143-150. - doi: 10.1641/0006-3568(2002)052[0143:PCAUDF] 2.0.CO;2

Gillis M (1988). West Africa: resource management policies and the tropical forest. In: "Public policies and the misuse of forest resources" (Repetto $\mathrm{R}$, Gillis $\mathrm{M}$ eds). Cambridge University press, Cambridge, UK, pp. 299-352.

GOB (2008). Bangladesh: road network improvement and maintenance project II. Ministry of Communication Roads and Highways Department, Dhaka, Bangladesh.

GOB (2010). Forest department official website. Government of people's Republic of Bangladesh, Dhaka, Bangladesh. [online] URL: http://www.bforest.gov.bd/land.php

Gorte RW, Sheikh PA (2010). Deforestation and climate change. CRS report. [online] URL: http://www.fas.org/sgp/crs/misc/R41144.pdf

Green KM (1981). Preliminary observation on the ecology and behavior of the capped Langur, Presbytis pileatus, in the Madhupur forest of Bangladesh. International Journal of Primatology 2: 131-151. - doi: 10.1007/BF02693445

Hossain MK (2005). Conversion of dipterocarp-dominat natural forests to short rotation plantations- an unrecoverable threat to the native dipterocarps in Bangladesh. APAFRI, Malaysia. Islam N (2005). Environmental issue in Bangladesh: an overview. Pakistan Journal of Social Science 3: 671-679. [online] URL: http://docsdrive.com/pdfs/medwelljournals/pjssci /2005/671-679.pdf

Khan JP, McDonald JA (1995). Third world debt and tropical deforestation. Ecological Economics 12: 107-123. - doi: 10.1016/0921-8009(94)000 24-P

Khan MASA, Uddin MB, Uddin MS, Chowdhury MSH, Mukul SA (2007). Distribution and status of forests in the tropics: Bangladesh perspective. Proceedings of the Pakistan Academy of Sciences 44: 145-153. [online] URL: http://paspk.org/downloads/Proc44-2/proc44-2-8.pdf Khan NA (1998). A political economy of forest resource use: Case studies of social forestry in Bangladesh. Ashgate Publishing Ltd. Aldershot. Martin J (1999). Population, poverty and vulnerability: mitigation the effect of natural disasters. [online] URL: http://www.fao.org/sd/wpdirect/ wpan0043.htm

Mena CF (2001). Deforestation in the Napo Basin: socio-economic factors, metrics, and patterns. M.Sc. Dissertation, Environmental Studies Department, Florida International University, Miami, FL, USA.

Muhammed N, Koike M, Haque F, Miah MD (2008). Quantitative assessment of people oriented forestry in Bangladesh: a case study from Tangail forest division. Journal of Environmental Management 88 (1): 83-92. - doi: 10.1016/j.jenvman.2007.01.029 
Muhammed N, Koike M, Sajjaduzzaman M (2005). A study on land tenure complexities of Sal (Shorea robusta) forests in Bangladesh. International Journal of Agriculture and Biology 7 (2): 318-320.

Munasinghe M (1993). Environmental economics and biodiversity management in developing countries. Ambio 22: 126-135. [online] URL: http://www.jstor.org/pss/4314057

Pant MM (1990). Forest resources management Field document No. 2, UNDP/FAO GBD/85/ 011, Institute of forestry, Chittagong University and FAO, Rome, Italy.

Rahman M (2010). Boner adibashider shonge nia bon rakha (Bengali). A report on national news paper "Protom Alo". [online] URL: http://www.prothom-alo.com/detail/date/2010-08-

11/news/85515

Repetto R (1988). Needed: new policy goals. American Forests 94: 58-64.

Rowe B, Sharma NP (1992). Deforestation: problems, causes, and concerns. In: "Managing the world's forest" (Sharma NP ed). Kendal/Hunt publishing, Iowa, USA.

Safa MS (2004). The effect of participatory forest management on the livelihood of the settlers in a rehabilitation program of degraded forest in Bangladesh. Small-scale Forest Economics, Management and Policy 3 (2): 223-238. [online] URL: http://www.springerlink.com/content/rwn2511863835078/

Salam MA, Noguchi T (2005). On sustainable development of social forestry in Bangladesh: Experience from Sal (Shorea robusta) forests. Environment, Development and Sustainability 7: 209-227. - doi: 10.1007/s10668-005-7313-3

Salam MA, Noguchi T (1998). Factors influencing the loss of forest cover in Bangladesh: an analysis from socio-economic and demographic perspectives. Journal of Forestry Research 3: 145-150. - doi: 10.1007/BF02762135

Shafik N (1994). Macroeconomics causes of deforestation: barking up the wrong tree? In: "The causes of tropical deforestation: the economic and statistical analysis of factors giving rise to the loss of tropical forests" (Brown K, Pearce
DW eds). University College London Press, London, UK.

Tucker M (1999). Can solar cooking save the forest? Ecological Economics 31:77-89. - doi: 10.1016/S0921-8009(99)00038-5

Turner IM (1996). Species loss in fragments of tropical rain forest: a review of the evidence. Journal of Applied Ecology 33(2): 200-209. doi: $10.2307 / 2404743$

Wunder S (2000). The economics of deforestation: the example of Ecuador. MacMillan and St. Martin Press, St. Anthony's College, London, UK, pp. 262.

WWF (1998). Living Planet Report 1998: overconsumption is driving the rapid decline of the world's natural environments. WWF, Gland, Switzerland.

Zikri M (2009). An econometric model for deforestation in Indonesia. Working paper in Economics and Development Studies No. 200903. Department of Economics, Padjadjaran University, Indonesia. 